\title{
Simulating Development of Science in a Country with the Use of the Cognitive Approach
}

\author{
Mykola $\mathrm{Kyzym}^{1}$, Olena Reshetniak ${ }^{2}$ and Oleksij Lelyuk ${ }^{2}$ \\ ${ }^{1}$ Research Centre for Industrial Problems of Development of NAS of Ukraine, Director, 1-a \\ Inzhenernyi Ln., Kharkiv, 61166, Ukraine \\ ${ }^{2}$ Research Centre for Industrial Problems of Development of NAS of Ukraine, Applicant, 1-a \\ Inzhenernyi Ln., Kharkiv, 61166, Ukraine
}

\begin{abstract}
The study proposes a methodological approach to justifying the directions for reforming the scientific sphere of a country which is based on the cognitive approach. Using the proposed approach, the groups of the main problems in the development of science in Ukraine are determined and indicators for their evaluation are singled out; the cognitive model of the development of science in Ukraine is constructed. On the basis of the constructed cognitive model, impulse simulation of the influence of the main factors on development of science in a country is carried out and, according to the hypotheses on the nature of their influence, four scenarios for the development of the process under study are constructed. The analysis of the developed scenarios allowed to justify the most effective measures to stimulate the development of science in Ukraine. The practical evaluation of the proposed methodological approach has proved the feasibility of using cognitive models for analyzing and simulating development of science in a country, which allows to quickly and accurately assess a situation and identify promising measures to support it.
\end{abstract}

\section{Introduction}

The development of modern society is directly linked to globalization processes which imply the strengthening of integration ties among regions and countries of the world. These processes also transform the development of science which is influenced by many internal and external factors having complex interrelations and affecting each other with different strength. All this makes the problem of simulating the development of science in countries of the world extremely difficult to analyze and puts forward requirements for the choice of tools to use. Many scientists have proved the feasibility of applying the cognitive approach in analyzing and simulating complex semistructured systems and problems, including the one under study [1]. The methodological foundations of the cognitive approach were laid in the works of R. Axelrod, Vesa A. Niskanen, R. Atkin, F. Ritter, A. S. Huff and others. They were further developed in works of Z. Avdeev, S. Kovriga, V. Maximov, V. Khaustova, and others [1-7]. But insufficient attention has been paid to studying processes of scientific development with the use of the cognitive approach. At the same time, its application will contribute to a better understanding of problems in the development of domestic science, identification of contradictions and a high-quality analysis of the entire system of research 
activity in Ukraine. Therefore, the aim of the article is studying the current problems in the development of the Ukrainian science and simulating its development in the context of globalization challenges by means of the cognitive approach.

\section{Methodology}

Cognitive simulation is based on representation of a complex system (problem) in a simplified form as a specific model and allows, based on it, to consider possible scenarios for the development of the system (problem) at certain external and internal changes.

The analysis of the existing in theory and practice approaches to diagnosing problems of functioning and development of a system (based on methods of goal-setting, strategic management, management theory, etc.) has proved the feasibility of using functional cognitive maps to represent knowledge about the development of problem situations to carry out a formal analysis of structural and dynamic features of the development of socioeconomic systems in solving practical problems of reforming an economic policy [1-7]. This made it possible to form a methodological approach to justifying the directions for reforming the scientific sphere in Ukraine, the block diagram of which is present in Fig. 1.

\section{Results}

In order to build a cognitive model for studying problems of science development in Ukraine, in accordance with the methodological approach to justifying the directions for reforming the country's scientific sphere (Fig. 1), at the first stage, directions for reforming the scientific sphere were determined based on forming a conceptual model of the research goals, structuring the goals, and defining the goal image. This process was implemented with the involvement of a group of experts, by analyzing the peculiarities, trends and problems in the development of science during the period of Ukraine's independence, as well as studying the experience in ensuring the development of science in the leading countries of the world. As a result of the study, there was justified the need to strengthen the export potential by increasing the share of high-tech products in the context of globalization, which can be achieved by enhancing the scientific and technical potential, improving the quality of scientific staff training, bringing the R \& D funding to the level of the leading countries of the world. It is these indicators that have formed the goal image of reforming the scientific sphere in the country.

At the second stage of the study, factors affecting the processes of research activity and the development of a scientific product were analyzed, which has allowed to form the problem domain, identify the main problems that are most significant as well as the main indicators for their evaluation (Table 1).

Table 1. Groups of main problems of science development in Ukraine and indicators for their assessment.

\begin{tabular}{|c|l|l|l|}
\hline $\begin{array}{c}\text { Deno- } \\
\text { tation }\end{array}$ & \multicolumn{1}{|c|}{ Problem } & \multicolumn{1}{|c|}{$\begin{array}{c}\text { Indicator for assessing the } \\
\text { problem }\end{array}$} & \multicolumn{1}{c|}{ Assessment } \\
\hline$X_{1}$ & $\begin{array}{l}\text { Low demand for science in } \\
\text { the economy }\end{array}$ & $\begin{array}{l}\text { Decrease in the share of } \\
\text { innovatively active enterprises }\end{array}$ & $\begin{array}{l}\text { Statistical assessment, calculating } \\
\text { the growth rate }\end{array}$ \\
\hline$X_{2}$ & $\begin{array}{l}\text { Inefficient system of state } \\
\text { management of science }\end{array}$ & $\begin{array}{l}\text { Lack of a strategy for the } \\
\text { development of science in the } \\
\text { country }\end{array}$ & $\begin{array}{l}\text { Expert assessment, linguistic rating, } \\
\text { determining uncertain tendencies }\end{array}$ \\
\hline$X_{3}$ & $\begin{array}{l}\text { Low level of } \\
\text { communication } \\
\text { (integration processes) }\end{array}$ & $\begin{array}{l}\text { Level of integration of scientific, } \\
\text { educational institutions and } \\
\text { business to create a scientific } \\
\text { product }\end{array}$ & $\begin{array}{l}\text { Expert assessment, linguistic rating, } \\
\text { determining uncertain tendencies }\end{array}$ \\
\hline$X_{4}$ & $\begin{array}{l}\text { Lack of funding and other } \\
\text { socio-economic incentives }\end{array}$ & R \& D funding & $\begin{array}{l}\text { Statistical assessment, calculating } \\
\text { the growth rate }\end{array}$ \\
\hline$X_{5}$ & Low level of effectiveness & Share of exports of high-tech & Statistical assessment, calculating \\
\hline
\end{tabular}




\begin{tabular}{|c|l|l|l|}
\hline & $\begin{array}{l}\text { of scientific results, low } \\
\text { export potential }\end{array}$ & products & the growth rate \\
\hline$X_{6}$ & Staffing problem & $\begin{array}{l}\text { Decrease in the number of } \\
\text { researchers }\end{array}$ & $\begin{array}{l}\text { Statistical assessment, calculating } \\
\text { the growth rate }\end{array}$ \\
\hline$X_{7}$ & $\begin{array}{l}\text { Low level of authority of } \\
\text { science in the society }\end{array}$ & Level of social status of scientists & $\begin{array}{l}\text { Expert assessment, linguistic rating, } \\
\text { determining uncertain tendencies }\end{array}$ \\
\hline
\end{tabular}

Source: developed by the authors
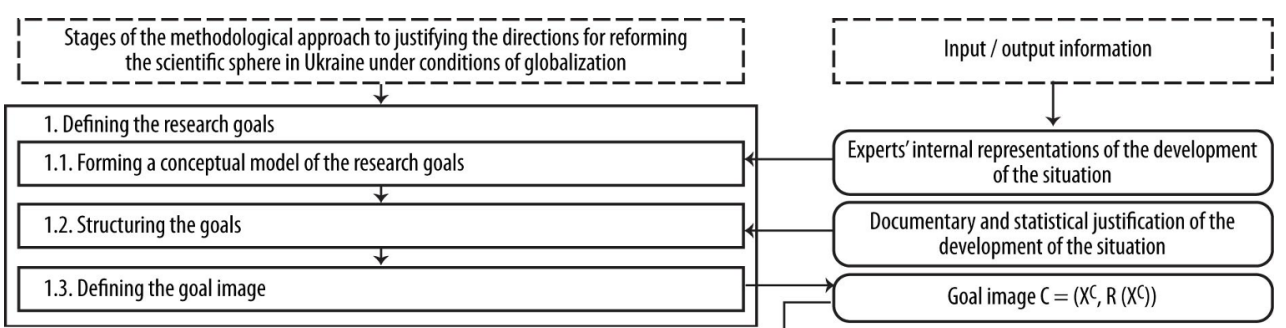

\begin{tabular}{|l|} 
1. Defining the research goals \\
1.1. Forming a conceptual model of the research goals \\
\hline 1.2. Structuring the goals \\
\hline 1.3. Defining the goal image \\
\hline
\end{tabular}

\begin{tabular}{|c|c|}
\hline \multicolumn{2}{|c|}{ 2. Studying the research object } \\
\hline \multirow{3}{*}{$\begin{array}{l}\text { 2.1. Describing } \\
\text { a problem } \\
\text { situation }\end{array}$} & 2.1.1. Fixing the situation \\
\hline & 2.1.2. Preliminary description of the problem \\
\hline & 2.1.3. Information search and complete description of the problem \\
\hline \multirow{3}{*}{$\begin{array}{l}\text { 2.2. Compiling } \\
\text { a catalog } \\
\text { of problems }\end{array}$} & 2.2.1. Compiling a list of problems based on a priori analysis \\
\hline & 2.2.2. Supplementing the catalog of problems \\
\hline & 2.2.3. Reducing the catalog of problems \\
\hline & \\
\hline \multirow{3}{*}{$\begin{array}{l}\text { 2.3. Forming } \\
\text { (grouping) } \\
\text { blocks of } \\
\text { problems }\end{array}$} & 2.3.1. Aggregation of the problems \\
\hline & 2.3.2. Breaking the problems out into blocks \\
\hline & $\begin{array}{l}\text { 2.3.3. Comparing problems and establishing cause-effect relations } \\
\text { among the problems in the blocks and among the problem blocks }\end{array}$ \\
\hline | & 2.3.4. Creating a primary (signed) cognitive map \\
\hline \multirow{4}{*}{\begin{tabular}{|l|} 
2.4. Determi- \\
ning the deg- \\
ree of impor- \\
tance of the prob- \\
lems, presen- \\
ting the blocks \\
of problems and \\
relations among \\
them
\end{tabular}} & 2.4.1. Determining the coefficients of importance of the problems \\
\hline & $\begin{array}{l}\text { 2.4.2. Calculating the normative coefficient of importance of the } \\
\text { problem and determining its type }\end{array}$ \\
\hline & 2.4.3. Determinine the relations among the problems \\
\hline & $\begin{array}{l}\text { 2.4.4. Constructing a formal cognitive map and a model for problem } \\
\text { solving }\end{array}$ \\
\hline
\end{tabular}

$$
\downarrow
$$

Experts' internal representations of the development of the situation

Documentary and statistical justification of the development of the situation

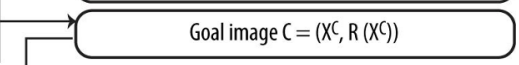

\section{Studying the research object}

2.1. Describing 2.1.1. Fixing the situation

L

\begin{tabular}{l} 
3. Simulating scenarios of development of the problem situation \\
$\begin{array}{l}\text { 3.1. Formulating alternative hypotheses for solving problems, alternative development } \\
\text { scenarios }\end{array}$ \\
\begin{tabular}{|l|} 
3.2. Implementing impulse simulation in accordance with the determined development \\
scenarios
\end{tabular} \\
\hline 3.3. Determining the tendencies at the vertices of the cognitive map \\
\hline 3.4. Assessing the results obtained \\
\hline 3.5. Developing recommendations for solving the problem situation \\
\hline
\end{tabular}

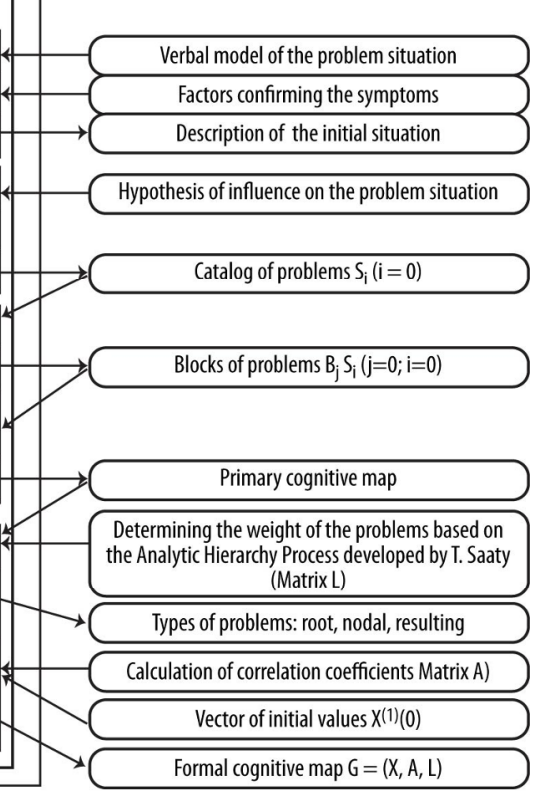

Determining the weight of the problems based on the Analytic Hierarchy Process developed by T. Saaty (Matrix L)

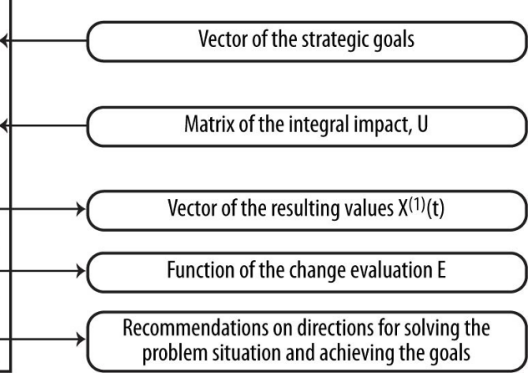

Fig. 1. Structural chart of the methodological approach to justifying the directions for reforming the scientific sphere in Ukraine.

Source: developed by the authors 
After identifying the main problems of the problem domain and building the primary cognitive map, the importance of the problems and connections between them was assessed based on the Analytic Hierarchy Process (AHP) developed by T. Saaty [8]. Accordingly, for this purpose, matrices of pairwise comparisons were formed and the effect of each problem which is included into another problem (or causes its occurrence) is determined.

Similarly, the matrices of pairwise comparisons for other groups of problems were formed and the effect of each problem which causes the emergence of others was determined. Based on the calculation of the weighing coefficients for problems in a group of problems, the types of problems are identified. The determination of root and nodal problems and their effect on other problems are given in Table 2.

Table 2. Determination of types of problems in the primary cognitive model

\begin{tabular}{|c|l|c|c|}
\hline $\begin{array}{c}\text { Deno- } \\
\text { tation }\end{array}$ & \multicolumn{1}{|c|}{ Group of problems } & $\begin{array}{c}\text { Weighting coefficient of } \\
\text { the problem in the group }\end{array}$ & $\begin{array}{c}\text { Type of } \\
\text { problem }\end{array}$ \\
\hline$X_{1}$ & Low demand for science in the economy & 0.509 & nodal problem \\
\hline$X_{2}$ & Inefficient system of state management of science & 3.922 & root problem \\
\hline$X_{3}$ & $\begin{array}{l}\text { Low level of communication (integration } \\
\text { processes) }\end{array}$ & 0.235 & nodal problem \\
\hline$X_{4}$ & $\begin{array}{l}\text { Lack of funding and other socio-economic } \\
\text { incentives }\end{array}$ & 0.456 & nodal problem \\
\hline$X_{5}$ & $\begin{array}{l}\text { Low level of effectiveness of scientific results, low } \\
\text { export potential }\end{array}$ & 0 & $\begin{array}{c}\text { resulting } \\
\text { problem }\end{array}$ \\
\hline$X_{6}$ & Staffing problem & 0.502 & nodal problem \\
\hline$X_{7}$ & Low level of authority of science in the society & 0.041 & nodal problem \\
\hline
\end{tabular}

Source: developed by the authors

At the next stage of the analysis, there were determined the values of the matrix $L$ which includes the value of the calculated coefficients of problem importance calculated based on the data of the State Statistics Service of Ukraine for the period 2000-2018 [9].

For some problems in the development of science, the impossibility to carry out a quantitative analysis of the indicators which characterize them was determined. Such problems are described by a linguistic variable and have an uncertain tendency in the development of indicators. To assess these problems, it was proposed to apply a rating scale using the approach which takes into account the Fibonacci series and the "golden proportion" based on expert assessment [10]. According to the proposed scale, the following problems were evaluated: the inefficient system of state management of science (insignificant increase - 1.119), a low level of communication (integration processes) 0.942 , a low level of authority of science in the life of the society -0.618 .

To determine the degree of the cause-effect relations of the problems in the development of science in Ukraine and the factors which characterize them, based on the matrices of statistical data describing their dynamics, the coefficients of correlation between the quantitative parameters of the influence of the factor $i$ on the factor $j$ were calculated. Measuring the causal factors and their weight, taking into account the correlation described by the matrix $A \times L$, is given in Table 3 .

Based on these calculations, a cognitive model for studying the problems of the development of science in Ukraine was built (Fig. 2). Based on the cognitive model, impulse simulation of the influence of factors on the development of science in Ukraine was carried out and, according to the formed hypotheses on the nature of their influence, four scenarios for the development of the studied processes were built.

Scenario 1 is based on the hypothesis that the development of science in the country will be influenced by forming and implementing an effective strategy for the development 
of science. It was simulated by introducing an impulse (disturbance) into the vertex $X_{2}$, the value of $\mathrm{u}_{1}=+1$.

Scenario 2 is based on the hypothesis that the development of science in the country will be influenced by increasing the $\mathrm{R} \& \mathrm{D}$ funding. It was simulated by introducing an impulse (disturbance) into the vertex $X_{4}$ the value of $\mathrm{u}_{4}=+1$. The disturbance (impulse) $U=\left\{u_{4}=0,0,0,+1,0,0,0\right\}$ simulates the hypothesis that at increasing R \& D funding a gradual increase in the share of high-tech products in the GDP is expected.

Table 3. Determining the values of the matrix $A \times L$ of measuring the causal factors and significance of the factors, taking into account their correlation.

\begin{tabular}{|c|l|c|c|c|c|c|c|c|}
\hline Denotation & \multicolumn{1}{|c|}{ Group of problems } & $X_{1}$ & $X_{2}$ & $X_{3}$ & $X_{4}$ & $X_{5}$ & $X_{6}$ & $X_{7}$ \\
\hline$X_{1}$ & $\begin{array}{l}\text { Low demand for science in } \\
\text { the economy }\end{array}$ & 0.000 & 0.000 & 0.000 & -0.146 & 0.132 & 0.000 & 0.000 \\
\hline$X_{2}$ & $\begin{array}{l}\text { Inefficient system of state } \\
\text { management of science }\end{array}$ & 0.504 & 0.000 & 0.618 & 0.543 & 0.226 & 0.257 & 0.379 \\
\hline$X_{3}$ & $\begin{array}{l}\text { Low level of communication } \\
\text { (integration processes) }\end{array}$ & 0.064 & 0.000 & 0.000 & 0.034 & 0.008 & 0.000 & 0.016 \\
\hline$X_{4}$ & $\begin{array}{l}\text { Lack of funding and other } \\
\text { socio-economic incentives }\end{array}$ & 0.000 & 0.000 & 0.000 & 0.000 & 0.272 & -0.018 & 0.000 \\
\hline$X_{5}$ & $\begin{array}{l}\text { Low level of effectiveness of } \\
\text { scientific results, low export } \\
\text { potential }\end{array}$ & 0.000 & 0.000 & 0.000 & 0.000 & 0.000 & 0.000 & 0.000 \\
\hline$X_{6}$ & Staffing problem & -0.037 & 0.000 & 0.000 & 0.000 & 0.143 & 0.000 & 0.104 \\
\hline$X_{7}$ & $\begin{array}{l}\text { Low level of authority of } \\
\text { science in the society }\end{array}$ & -0.013 & 0.000 & 0.000 & 0.000 & 0.000 & 0.000 & 0.000 \\
\hline
\end{tabular}

Source: developed by the authors based on [9]

Low level of authority of science in the society $\left(\mathrm{X}_{7}\right)$
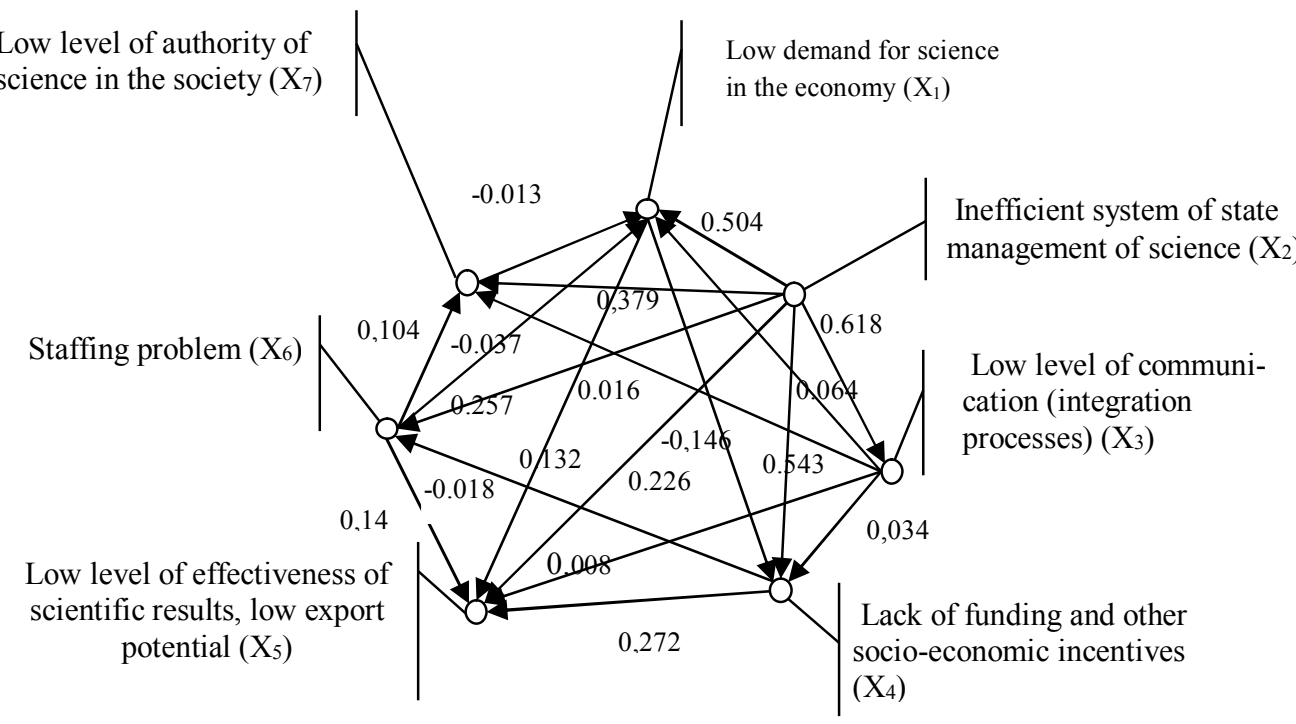

Fig. 2. Cognitive model for studying problems in the development of science in Ukraine Source: developed by the authors.

Scenario 3 is based on the hypothesis that the development of science in the country will be influenced by enlarging the number of researchers due to improving the quality of 
scientific staff training. It was simulated by introducing an impulse (disturbance) into the vertex $\mathrm{X}_{6}$, the value of $\mathrm{u}_{6}=+1$. The disturbance (impulse) $U=\left\{u_{6}=0,0,0,0,0,+1,0\right\}$ simulates the hypothesis that at enlarging the number of researchers, due to improving of the quality of scientific staff training, a gradual increase in the share of high-tech products in the GDP is expected.

Scenario 4 is based on the hypothesis that the development of science in the country will be influenced by forming and implementing an effective strategy for the development of science along with increasing the $\mathrm{R} \& \mathrm{D}$ funding and enlarging the number of researchers due to improving the quality of scientific staff training. It was simulated by introducing an impulse (disturbance) into the vertex $X_{2}$, the value of $\mathrm{u}_{1}=+1$; introducing a disturbance into the vertex $x_{4}$, the value of $u_{4}=+1$; introducing an impulse into the vertex $x_{6}$, the value of $u_{6}=+1$. The disturbance (impulse) $U=\{0,+1,0,+1,0,+1,0\}$ simulates the hypothesis that at formulating an adequate policy for the development of science and elaborating a strategy for the development of science in Ukraine, enlarging the number of researchers due to improving the quality of scientific staff training, increasing $R$ \& D funding a gradual increase in the share of high-tech products in the GDP is expected.

The analysis of the scenarios for the development of science in Ukraine, built on the basis of a cognitive model of the existing problems, has made it possible to determine that at present the most effective way, which will bring the most significant results (all parameters of the goal image increase), is forming and implementing an effective strategy for the development of science. Enlarging the number of researchers by improving the quality of scientific training and increasing R\&D funding under conditions which have developed in the country will not yield significant results without paying attention to strategic priorities in the development of science and relevant government support.

\section{Conclusions}

Thus, the proposed methodological approach has allowed to justify the most effective measures to stimulate the development of science in Ukraine. The practical evaluation of the proposed methodological approach has proved the feasibility of using cognitive models for analyzing and simulating development of science in a country, which allows to quickly and accurately assess a situation and determine promising measures to support it.

\section{References}

1. Vesa A. Niskanen. Theoretical advances and applications of fuzzy logic and soft computing, 42, 119-127 (2007).

2. Ritter F. E., Major N. P. Useful mechanisms for developing simulations for cognitive models. AI and Simulation of Behaviour Quarterly, 91, 7-18 (1995).

3. Huff S. Mapping strategic thought. Chichester, UK: Wiley, 11-49 (1990).

4. Avdeeva Z., Kovriga S. The technology of the strategic goal-setting and monitoring of a system development on the basis of cognitive mapping. Procedia Computer Science, 122, 977-984 (2017). https://www.sciencedirect.com/science/ article/pii/S1877050917327163

5. Kyzym M. O., Uzunov V. V. Program-Targeted Approach to State Management of Social Tension in the Regions of the Country. Kharkiv, PH "INZHEK", 224. (2008)

6. Khaustova V. Ye., Zinchenko V. A., Moschitskaya T. A. Business Inform, 12 (2), 200203 (2009)

7. Tishchenko A. N., Khaustova V. Ye. International Economic Journal Economic Cybernetics, 1-2 (55-56), 54-57 (2009). 
8. Saaty T., Sodenkamp M. Making decisions in hierarchic and network systems. Int. J. Applied Decision Sciences, 1, 24-79 (2008).

9. The State Statistics Service of Ukraine (2019). http://www.ukrstat.gov.ua/

10. Davydov A. A., Churakov A. N. Modular analysis and modeling of society. Moscow, Institute of Sociology, 208. (2000). 